\title{
THE IMPORTANCE OF EARLY SUSPICION OF NON-MELANOCYTIC MALIGNANT SKIN CANCER (NMSC) IN PRIMARY AND SECONDARY HEALTH CARE
}

\section{ZNAČAJ RANE SUMNJE NA NEMELANOCITNE MALIGNE TUMORE KOŽE (NMSC) U PRIMARNOJ I SEKUNDARNOJ ZDRAVSTVENOJ ZASTITI}

\author{
Spomenka Paurević, Darko Lukić2 , Jozo Grgić3 , Nenad Babić ${ }^{2}$, Duško Ivić, Predrag Lazić
}

\section{Summary}

The prospective study, which took place from February 2011 to March 2014, included respondents who were sent for computerized dermoscopy because of non-melanocytic skin tumours. Respondents were divided into 2 groups. The first one, group A (45 respondents), consisted of respondents who had expressed concern about the observed changes in the skin and the desire for examination. The second one, group B (50 respondents) were respondents that did not come for examination due to changes on the skin, but for other reasons, so they had indirectly detected suspicious skin lesions.

The aim of this study is to analyse the importance of early suspicion of non-melanocytic malignant skin tumours by specialists in primary and secondary health care.

Parameters for comparison were respondents' subjective attitude of non-pigment skin lesions and dermoscopy and/or PH findings.

It has been shown that changes in the skin that bleed are sometimes highly suspect of NMSC because group A had 5 such cases and NMSC was detected in 4 cases, and group B had 7 respondents with haemorrhage and there were 4 with NMSC.

In group $B$, out of 12 respondents who said that they had found suspicious skin lesions caused by trauma, there were 8 NMSC, while in group A there were 3 cases, which is a statistically significant difference. In group B, out of 16 respondents who claimed that they had had suspicious skin changes dormant for years, NMSC has been proven in 3 cases, and in group A there was not NMSC which is also a statistically significant difference.

It was confirmed that the claims of the respondents are unreliable and that all patients should be addressed to computer dermoscopy, in patients with visible changes that arise even a slightest suspicion of NMSC.

Keywords: skin, cancer, dermoscopy.

\section{Sažetak}

Prospektivnom studijom, koja je trajala od februara 2011.godine do marta 2014. godine, obuhvaćeni su ispitanici koji su upućeni na kompjutersku dermoskopiju radi nemelanocitnih tumora kože. Ispitanici su podijeljeni u 2 grupe. Prvu, grupu A (45 ispitanika), činili su ispitanici koji su sami izrazili zabrinutost zbog uočene promjene na koži i želju za pregledom. Drugu, grupu B (50 ispitanika), činili su ispitanici koji nisu došli radi promjena na koži, nego iz drugih razloga, ali su im posredno uočene sumnjive kožne lezije.

Cilj rada je analiza značaja rane sumnje na nemelanocitne maligne kožne tumore od strane specijalista primarne i sekundarne zdravstvene zaštite.

Parametri za poređenje bili su subjektivni stav ispitanika o nepigmentnim lezijama kože i dermoskopski i/ili PH nalaz.

Dokazano je da su promjene na koži koje povremeno krvare visoko suspektne na NMSC jer je u grupi A od 5 takvih slučajeva NMSC su dokazani u 4 slučaja, a u grupi B od 7 ispitanika sa krvarenjem kod 4 se radilo o NMSC.

U grupi B od 12 ispitanika koji su iznijeli tvrdnju da su im sumnjive kožne promjene posljedica traume dokazano je 8 NMSC a u grupi A u 3 slučaja što je statistički značajna razlika. U grupi B od 16 ispitanika koji su iznijeli tvrdnju da im sumnjive kožne promjene godinama miruju dokazano je 3 NMSC a u grupi A nije bilo NMSC što je takođe statistički značajna razlika.

Potvrđeno je da su tvrdnje ispitanika nepouzdane te da na kompjutersku dermoskopiju treba uputiti sve pacijente kod kojih postoje vidljive promjene koje pobuđuju i najmanju sumnju na NMSC.

Ključne reči: koža, karcinom, dermoskopija

\section{INTRODUCTION}

All skin cancers, except for melanoma, are referred to as non-melanoma skin cancers (NMSC). The two most common non-melanoma skin cancers (NMSC) are the basal cell cancer (BCC) and squamous cell cancer (PCC). Both types of cancer occur more frequently in males. NMSC appears most frequently in adults, but can be seen in children as well (1). 
BCC is the most common cancer in human population. The incidence of BCC in Europe is 100 per 100,000 inhabitants and in Australia it is 900 per 100,000 inhabitants (1).

BCC and PCC make up about $95 \%$ of all skin cancers, whereas melanoma makes about $4 \%$ and $1 \%$ are other rare skin cancers. The number of NMSC is increasing. In the USA in 2010 there were diagnosed 3.5 million diagnosed with NMSC per 2,000,000 patients (2).

The most important carcinogen for the skin is ultraviolet radiation, which causes DNA mutations, alteration of the genome and the uncontrolled growth of cancer cells. About $80 \%$ of skin cancer (except for melanoma) is formed on the skin exposed to the sun, and around 30\% of NMSC occurs in the region around nose (3).

NMSC grow slowly and develop over the years. Since NMSC usually appears on face and scalp, it is very important during the treatment to take care of the functional and later aesthetic result. Of course, the basic principle of treating of NMSC should never be neglected - timely radical cancer removal.

Clinical diagnosis of pigmented skin lesions and non-pigmented is not often correct (3-6). In cases when NMSC is suspected, it is wise to examine the suspicious lesion by using computer dermoscopy. The accuracy of digital computer dermoscopy, in relation to the $\mathrm{pH}$ analysis, is from 98 to $100 \%$ (6).

Dermoscopy is now widely used in the EU, the USA and Australia. It is non-invasive, painless and bloodless, a superficial contact of microscope, with "in vivo" visualization of structure in epidermis and dermis, i.e. detection of changes that are not visible to the inspection review, scrutiny or human eye. This diagnosis does not imply any harmful effects and can be repeated indefinitely, regardless of the patient's age (4).

\section{Aim OF THE STUDY}

The aim of this study is analysing the importance of early suspicion of non-melanocytic malignant skin tumours (NMSC) by specialists in primary and secondary health care.

\section{RESPONDENTS AND METHODS}

The prospective study, which lasted from February 2011 to March 2014, included respondents who were referred to computerized dermoscopy because of non-melanocytic skin tumours. The respondents were divided into 2 groups.
The first one, group A (45 respondents), consisted of respondents who had expressed concern about the observed changes on the skin and had desire to be examined.

The second one, group B (50 respondents), contained the respondents that had not come for examination due to changes on the skin, but for other reasons, but suspicious skin lesions were indirectly detected.

For arriving at diagnosis the following were used: anamnesis, clinical examination and computerized dermoscopy, and definitive $\mathrm{PH}$ analysis after excision. Parameters for comparison were the subjective attitude of respondents about non-pigment skin lesions and dermoscopy and / or PH findings.

The observed parameters during the analysis were the following: gender, age, anatomical position of cutaneous tumours, as shown in Tables 1-3.

\begin{tabular}{|lrl|}
\hline \multicolumn{3}{c}{ Table 1. Gender of respondents } \\
\hline Gender of respondents & \multicolumn{1}{c}{ Group A } & Group B \\
\hline Male & $16(35,5 \%)$ & $32(64 \%)$ \\
\hline Female & $29(64,5 \%)$ & $18(36 \%)$ \\
\hline Total & $45(100 \%)$ & $50(100 \%)$ \\
\hline & Table 2. Age of respondents \\
\hline Age of respondents & Group A & Group B \\
\hline $20-30$ & $8(17,7 \%)$ & $9(18 \%)$ \\
\hline $30-40$ & $7(15,6 \%)$ & $9(18 \%)$ \\
\hline $40-50$ & $8(17,7 \%)$ & $13(26 \%)$ \\
\hline $50-60$ & $12(26,6 \%)$ & $8(16 \%)$ \\
\hline Over 60 & $10(22,3 \%)$ & $11(22 \%)$ \\
\hline Total & $45(100 \%)$ & $50(100 \%)$ \\
\hline
\end{tabular}

Table 3. Location of tumour

\begin{tabular}{|lll}
\hline Location of tumour & Group A & Group B \\
\hline Forehead & $3(6,6 \%)$ & $4(8 \%)$ \\
\hline Face $($ cheeks) & $8(17,7 \%)$ & $10(20 \%)$ \\
\hline Nose & $5(11,2 \%)$ & $8(16 \%)$ \\
\hline Earlobes & $4(8,8 \%)$ & $3(6 \%)$ \\
\hline Upper eyelids & $1(2,3 \%)$ & $3(6 \%)$ \\
\hline Lower eyelids & $4(8,8 \%)$ & $2(4 \%)$ \\
\hline Scalp & $7(15,6 \%)$ & $5(10 \%)$ \\
\hline Neck & $4(8,8 \%)$ & $4(8 \%)$ \\
\hline Upper extremity & $2(4,9 \%)$ & $1(2 \%)$ \\
\hline Lower extremity & $1(2,3 \%)$ & $0(0 \%)$ \\
\hline Back & $3(6,7 \%)$ & $5(10 \%)$ \\
\hline Chest & $3(6,7 \%)$ & $5(10 \%)$ \\
\hline Total & $45(100 \%)$ & $50(100 \%)$ \\
\hline
\end{tabular}

\section{Results}

The research results are shown in Tables 4 and 5 and Figures 1 and 2. The parameters for comparison were 
the following: subjective attitude to non-pigment skin lesions and dermoscopic and / or PH findings.

Table 4. Respondents' attitude to non-pigment skin changes and the reason of (not)

$$
\text { coming for examination }
$$

\begin{tabular}{|c|c|c|}
\hline $\begin{array}{l}\text { Respondents' attitudes to } \\
\text { non-pigment skin changes } \\
\text { and the reason of (not) com- } \\
\text { ing for examination }\end{array}$ & Group A & Group B \\
\hline $\begin{array}{l}\text { There are fears of non-pig- } \\
\text { ment skin change }\end{array}$ & $15(33,3 \%)$ & $4(8 \%)$ \\
\hline $\begin{array}{l}\text { The change is the result of hit- } \\
\text { ting - trauma }\end{array}$ & $3(6,7 \%)\left({ }^{*}\right)$ & $12(24 \%)\left({ }^{*} 8\right)$ \\
\hline Change occasional bleeding & $5(11,2 \%)\left({ }^{\star} 4\right)$ & $7(14 \%)\left({ }^{\star} 4\right)$ \\
\hline $\begin{array}{l}\text { The change is the same for } \\
\text { several years }\end{array}$ & $6(13,4 \%)$ & $16(32 \%)\left({ }^{*} 3\right)$ \\
\hline The change increases & $12(26,6 \%)\left({ }^{\star} 1\right)$ & $8(16 \%)\left({ }^{*} 1\right)$ \\
\hline Aesthetic problem & $4(8,8 \%)$ & $3(6 \%)$ \\
\hline Total & $45(100 \%)$ & $50(100 \%)$ \\
\hline
\end{tabular}

\section{* $=$ NMCS}

Figure 1. Attitude of respondents about non-pigment skin change and the reason of (not) coming for examination

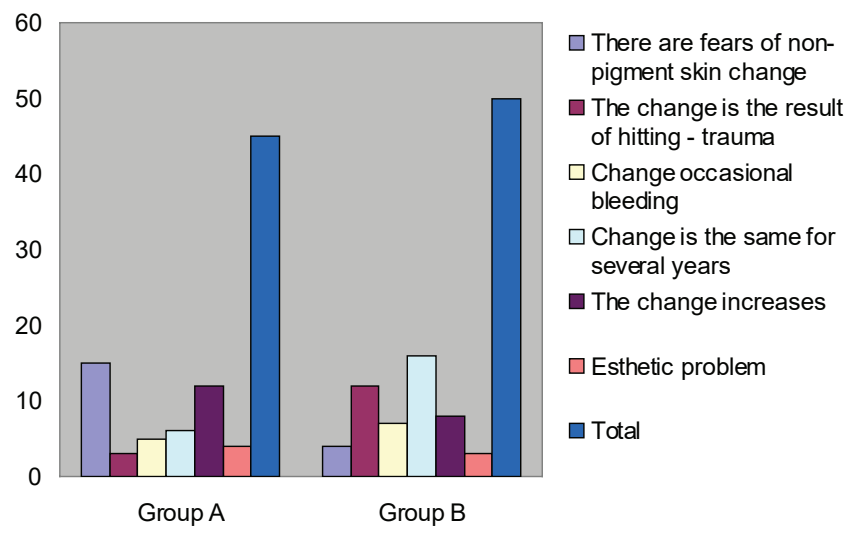

Table 5. Dermoscopic and / or PH findings

\begin{tabular}{lll}
$\begin{array}{l}\text { Dermoscopic and } \\
\text { PH findings }\end{array}$ & Group B \\
$\begin{array}{l}\text { Benign non-melano- } \\
\text { cytic tumour }\end{array}$ & $37(82,1 \%)$ & $34(68 \%)$ \\
\hline BCC & $5(11,2 \%)$ & $15(30 \%)$ \\
PCC & $3(6,7 \%)$ & $1(2 \%)$ \\
Total & $45(100 \%)$ & $50(100 \%)$ \\
\hline
\end{tabular}

Figure 2. Dermoscopic and /or PH findings

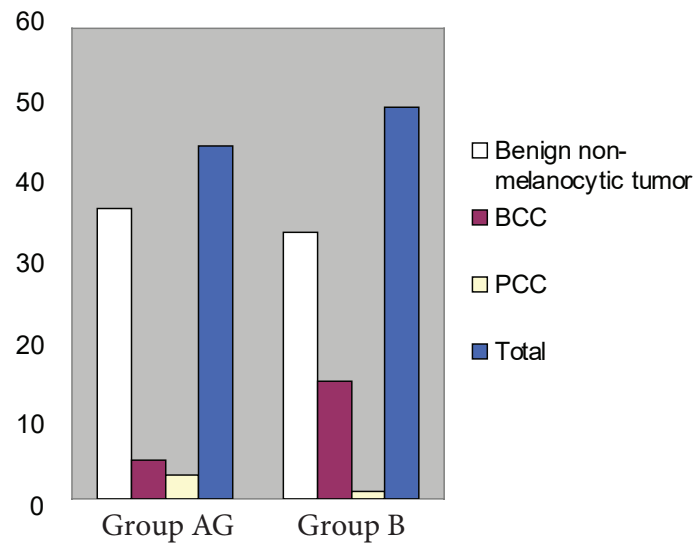

By statistical analysis between the observed groups A and $\mathrm{B}$, the following was ascertained:

- In terms of the characteristics of respondents' attitude-fear of non-pigmented skin changes, there is a statistically significant difference $(\mathrm{p}<0.01$, reliability 99\%), $\mathrm{Z}=2.293478$

- In terms of the characteristics of respondents' attitude- the change is the result of hitting (trauma) there is a statistically significant difference $(\mathrm{p}<0.01$, reliability 99\%), $Z=2.86201$

- In terms of the characteristics of respondents' attitude - change is the same for several years, there is a statistically significant difference $(\mathrm{p}<0.01$, reliability 99\%), $Z=2.764289$

- In terms of the characteristics of BCC skin PH finding there is a statistically significant difference ( $\mathrm{p}<0.01$, reliability 99\%), $\mathrm{Z}=2.452421$

\section{Discussion}

The analysis included 95 subjects, 48 males and 47 females. In group A women are almost twice more likely to come to the examination then men. This can be explained as a higher concern of the female population with changes on the skin. On the contrary, in group B male respondents are twice more likely to have had a legitimate reason for dermoscopic examination. This at the same time showed that women are more responsive to changes on the skin, and that suspicious changes more often appear on male skin.

NMSC are usually positioned on body parts that are most exposed to the sun. The skin that has been damaged by UV rays with the visible solar spots and actinic keratosis is predilective place for NMSC (4-7). Dominant anatomical region where NMSC was registered in our respondents is the head (scalp, face, nose), which is consistent with the data from literature.

Skin examination was often required by patients who had a completely irrational fear of skin tumour (8).

In group A, 15 respondents came for examination because of irrational, general fear of skin lesions and desire to check it. In group B only 4 respondents had the attitude of fear of non-pigmented skin changes, which proved to be statistically significantly different. However, in Group A out of 15 respondents who came for examination only due to irrational fear of existing skin lesions, NMSC was not detected in any of those cases.

A large number of individuals with obvious changes on the skin ignore them or deny the disease, explaining skin lesions to be the result of injury or some other trivial coincidence (4). 
In group $\mathrm{B}$, the dominant respondent's attitude was that their non-pigmented tumorous lesions were caused by trauma. Namely, there were significantly different efforts among respondents from group B compared to those from group A, to attribute the formation of skin lesions to previous violation and not to disease and tumour hearth. This attitude can be explained as subjective rationalization and escape from the fact that there is a skin tumour. At the same time, among 12 patients from group $\mathrm{B}$, who alleged changes to violation of the skin, NMCS was found in $8(66,6 \%)$.

One respondent from group B who was recommended dermoscopy due to changes on the nose, and suspicion of BCC, resisted having dermoscopic examination for a long time, as well as operation itself. He insisted that the change on the nose was not a tumour but the consequence of frequent injuries during washing his face, because his fingers were bent due to Dupuytren's contracture. Dermoscopy and PH findings confirmed BCC.

Basal cell carcinoma (BCC) is the most commonly occurring NMSC, it appears first on the head, especially on the face and rarely on the palms or feet. BCC is primarily described as a small, inconspicuous, irregular, reddish change that can create discrete ulceration. The lesion bleeds occasionally as tumour progresses. Slow tumour development can be visible for many years (4-9).

Transient slight bleeding from the skin non-melanocytic lesion proved to be a significant priority for early suspicion of NMSC in our respondents. Out of 5 patients with occasional bleeding from skin lesions in group A NMSC were confirmed in $4(80 \%)$ of them. In group B, out of 7 patients with the same symptoms, NMSC was also found in $4(57,1 \%)$ of them.

NMSC often begins as a seemingly harmless erosion of the epidermis, or as a small sore that takes long to heal. It usually heals by forming scabs, which spontaneously fall off, but leaves a vulnerable area. Eventually, the vulnerable area increases and becomes irregularly edged. This genesis changes deceive many patients (7).

In some cases, NMSC, especially BCC, can give the appearance of a fully rehabilitated incrusted skin changes (9). That is the reason why a larger number of lay people do not think it is a dangerous cutaneous lesion. Such changes may be misleading to clinicians as well (10).

In our respondents from group B, 16 of them (32\%) had the current change on the skin considered harmless, primarily because it "suspended" for years. It has been shown that among these lesions there were $3(18,7 \%)$ NMSC. In group A, $6(13,3 \%)$ respondents reported a long time non-pigmented, motionless skin changes but it turned out that among them there were not NMSC. By this characteristic was observed as a significant difference.
Most NMSC have a limited potential for growth, but they can be very aggressive and then reach a considerable size and penetrate deeply. On the face they can ruin eyes and nose or penetrate through the skull and attack meninges. In this form NMSC is fatal (11).

Therefore, the early suspicion of NMSC is crucial. Quick diagnosis allows timely and optimal radical surgery by which the local tumour is removed in its entirety and the aesthetic appearance of the patient are in the area of disfigurement. In our respondents in both groups very aggressive NMSC were not found.

In our respondents in group A, NMSC was diagnosed in the total of $8(17,8 \%)$ respondents, and in group B in 16 (32\%) respondents. At the same time, significant statistical difference was observed in terms of the incidence of basal cell cancer (BCC) because it was proven three times more common in the patients from group $\mathrm{B}$.

Various studies have established certain parameters and risk factors that lead to the progression and dissemination of NMSC. These are macroscopic parameters (size, shape and multifocality of tumours) and the microscopic parameters (degree of cell differentiation) (12).

Generally, NMSC is not characterized by aggressive mood with a rapid formation of metastases. Cancers that occur on sun-damaged skin, have a very low susceptibility to metastasis, with the incidence of approximately $0.5 \%$ (11). On the contrary, NMSC incurred after inflammation and degenerative processes have a much higher degree of metastasising than those which develop on sun-damaged skin (13).

During our analysis there were no verified cases of disseminated forms of NMSC.

\section{Conclusion}

It has been shown that changes on the skin that sometimes bleed are highly suspicious of NMSC because in group A NMSC were detected in 4 out of cases, and in group B NMSC was discovered in 4 out of 7 respondents with haemorrhage.

In group B NMSC was proven in 8 out of 12 respondents who presented with the claim that their suspicious skin lesions were caused by trauma, and in group A in there were 3 cases, which is a statistically significant difference. In group B NMSC was proven in 3 out of 16 respondents who presented with a claim that their suspicious skin changes were dormant for years, whereas in group A there were no NMSC, which is also a statistically significant difference. 
It was confirmed that the claims of respondents were unreliable and that all patients should be referred to the computer dermoscopy if there are visible changes that give rise to the slightest suspicion of NMSC.

\section{References}

1. Lear JT, Smith AG. Basal cell carcinoma. Postgrad Med J 1997;73:538542.

2. Rogers, HW, Weinstock, MA, Harris, AR, et al. Incidence estimate of nonmelanoma skin cancer in the United States, 2006. Arch Dermatol 2010; 146(3):283-287.

3. Padgett JK, Hendrix JD Jr. Cutaneous malignancies and their management. Otolaryngol Clin North Am 2001;34:523-553

4. Lukić D.: Tumori kože, Medicinski fakultet Banja Luka, 2009: 45:52

5. Lukić D, Bandić J, Ivić D. Rezultati lečenja planocelularnog i bazocelularnog kercinoma kože glave i vrata i drugih anatomskih regija. Medicinska istraživanja, 2006;40(1): 29-35.

6. Anwar, U., Ghazal, A.S.K., Ahmad, M., Sharpe, D.T. Horrifying basal cell carcinoma forearm lesion leading to shoulder disarticulation. Plast Reconstr Surg, 2006; 117-9

7. McCutcheon, B., White, K., Kotwall, C., Germolic, D., Rebolloso, Y., Hamann, M.S., Stiles, A. A preliminary study of imiquimod treatment in variants of basal cell carcinoma. Am Surg,2005; 71(8): 662-5
8. Deo SV, Hazarika S, Shukla NK, Kumar S, Kar M, Samaiya A. Surgical management of skin cancers: Experience from a regional cancer centre in North India. Indian journal of cancer. 2005; 42(3): 145-150.

9. Eisner, J.M., Russell, M. Cartilage hair hypoplasia and multiple basal cell carcinomas. J Am Acad Dermatol, 2006: 54-58

10. Hutcheson, A.C., Fisher, A.H., Lang, P.G. Basal cell carcinomas with unusual histologic patterns. Journal of the American Academy of Dermatology, 2005; 53(5): 833

11. Asilian, A., Tamizifar, B. Aggressive and neglected basal cell carcinoma. Dermatologic Surgery, 2005; 31(11, Pt. 1), 1468-1471

12. Pennington BE, Leffe DJ. Mohs micrographic surgery: Established uses and emerging trends. Oncology, Willston Park, Aug. 2005; 19(9): 1165 1171.

13. Braun-Falco O, Plewig G, Wolff HH, Winkeimann RK. Malignant epithelial tumors. In: Braun Falco O, Plewig G, Wolff HH, Winkeimann RK. (Ed.) Dermatology, Berlin: Springer-Verlag, 1991:1018-1135. 